\title{
Aseptic meningoencephalitis mimicking transient ischaemic attacks
}

\author{
V. Papavasileiou $\cdot$ H. Milionis $\cdot$ M. Cordier $\cdot$ \\ A. Eskandari · G. Ntaios $\cdot$ P. Michel
}

Received: 7 August 2012/Accepted: 22 December 2012/Published online: 17 January 2013

(C) Springer-Verlag Berlin Heidelberg 2013

\begin{abstract}
Purpose To highlight meningoencephalitis as a transient ischaemic attack (TIA) mimic and suggest clinical clues for differential diagnosis.

Methods This was an observational study of consecutively admitted patients over a 9.75-year period presenting as TIAs at a stroke unit.

Results A total of 790 patients with TIAs and seven with TIA-like symptoms but a final diagnosis of viral meningoencephalitis were recognised. The most frequent presentations of meningoencephalitis patients were acute sensory hemisyndrome (6) and cognitive deficits (5). Signs of meningeal irritation were minor or absent on presentation. Predominantly lymphocytic pleocytosis, hyperproteinorachia and a normal cerebrospinal fluid (CSF)/serum glucose index (in 5 out of 6 documented patients) were present. Meningeal thickening on a brain magnetic resonance imaging (MRI) scan was the only abnormal imaging finding. Six patients received initial vascular treatment; one thrombolysed. Finally, six patients were treated with antivirals and/or antibiotics. Although neither bacterial nor
\end{abstract}

V. Papavasileiou · G. Ntaios

Department of Medicine, University of Thessaly,

41110 Biopolis, Larissa, Greece

V. Papavasileiou $\cdot$ H. Milionis $\cdot$ M. Cordier $\cdot$ A. Eskandari ·

G. Ntaios · P. Michel $(\bowtie)$

Stroke Unit, Neurology Service, University of Lausanne,

Centre Hospitalier Universitaire Vaudois, BH13/204,

Rue de Bugnon 46, 1011 Lausanne, Switzerland

e-mail: patrik.michel@chuv.ch viral agents were identified on extensive testing, viral meningoencephalitis was the best explanation for all clinical and laboratory findings.

Conclusions Aseptic meningoencephalitis should be part of the differential diagnosis in patients presenting as TIA. The threshold for a lumbar puncture in such patients should be set individually and take into account the presence of mild meningeal symptoms, age and other risk factors for vascular disease, the results of brain imaging and the basic diagnostic work-up for a stroke source.

Keywords Mimics - Stroke - Transient ischaemic attack · Meningitis · Encephalitis

\section{Introduction}

Stroke and transient ischaemic attack (TIA) mimics comprise a heterogeneous group of non-vascular conditions, including seizures, migraine with aura, brain tumours, hypertensive, toxic, metabolic and infectious encephalopathies [1-3]. In clinical practice, the initial distinction of stroke and TIA from their mimics is based on epidemiological and clinical clues, which guide further diagnostic testing in the acute setting [4].

Infectious meningoencephalitis is a disease caused by different bacterial or viral agents and with a wide spectrum of clinical presentations [5-11]. There is a scarcity of data regarding meningoencephalitis presenting initially as a cerebrovascular mimic. Hereafter, we describe a consecutive case series of such patients admitted to the stroke unit of a tertiary care hospital over a 9.75-year period who were eventually diagnosed as meningoencephalitis and successfully treated as such. 


\section{Materials and methods}

Design and study population

All patients above the age of 16 years with an initial suspicion of TIA, between April 2002 and December 2011, who were hospitalised in the Stroke Unit of the Centre Hospitalier Universitaire Vaudois (CHUV, Lausanne, Switzerland) and whose discharge diagnosis was either TIA or meningoencephalitis, were registered by one of the authors (P.M.). Details of the medical records were then extracted retrospectively from the electronic medical records for the patients with central nervous system (CNS) infection.

The historical TIA definition of rapidly developed clinical signs of a focal neurological disturbance of presumed arterial origin lasting $<24 \mathrm{~h}$ was used for both groups of patients [12], independently of whether an acute ischaemic lesion was present on imaging or not. Meningoencephalitis was defined as an acute infection within the sub-arachnoid space, as indicated by cerebrospinal fluid (CSF) pleocytosis with white blood cell count (WBC) $>5 / \mu \mathrm{L}$, also involving the brain parenchyma, as connoted by the presence of associated neurological symptoms or findings. Patients with meningoencephalitis accompanied by imaging-confirmed stroke were excluded.

According to the legislation of Canton de Vaud, no ethical approval is required for this type of study. The president of the ethics commission for research on humans of the Canton and the institution's medical director have waived the medical secret for all co-authors for this study.

\section{Investigations}

All patients were investigated with at least one magnetic resonance imaging (MRI) scan, including diffusionweighted imaging (DWI), and most also had initial non-contrast head computed tomography (NCCT), CT angiography (CTA) and CT perfusion (CTP). All patients underwent at least one arterial study of the neck and brain arteries [Doppler, MR angiography (MRA) or CTA]. Further work-up for potential causes of TIA was performed in a standardised fashion, as described in a previous report [13], and included continuous monitoring of vital and neurological signs, and partially individualised haematological and cardiac tests. Lumbar puncture (LP) was performed upon the treating neurologist's recommendation when (even minor) meningeal symptoms were present, when work-up for stroke showed neither a source nor an atherosclerotic lesion or when DWI was normal. CSF was analysed for the CSF/serum glucose ratio, proteins, cell count and white cell distribution. Further work-up to identify a causative agent included: (1) serologic testing for herpes simplex virus, varicella zoster virus, Epstein-Barr virus, cytomegalovirus, Borrelia burgdorferi, Brucella melitensis, Toxoplasma and Treponema, (2) CSF bacterial cultures and (3) CSF polymerase chain reaction (PCR) for herpes simplex virus, varicella zoster virus, Borrelia burgdorferi, mycobacteriums and bacterial DNA. Electroencephalogram (EEG) was performed in case of suspicion of epileptic seizures or confusional state.

\section{Results}

Frequency and demographics

During the 9.75-year observation period, 790 patients with a discharge diagnosis of a TIA (age 71 years, interquartile range 59-80 years) were hospitalised in our stroke unit. In 27 of these patients (age 52 years, interquartile range 41-60 years, 13 males), the diagnostic work-up included an LP. In the same period, five Caucasian males and two females with a median age of 45 years (range 22-75 years) presented with meningoencephalitis imitating TIA $(0.16 \%$ of all ischaemic strokes and TIAs). We excluded three patients with stroke due to meningovascular neuroborreliosis [14], neurovascular syphilis and toxoplasmosis abscess, respectively.

\section{Clinical presentation}

All patients had sudden onset of focal neurological symptoms, except for patient no. 7, whose facio-brachial hypoaesthesia developed over $5 \mathrm{~min}$. The duration of symptoms ranged from $45 \mathrm{~min}$ to $17 \mathrm{~h}$ and $30 \mathrm{~min}$ (median $510 \mathrm{~min}$ ), and the delay between focal neurological symptoms onset and first hospital arrival ranged from 1.6 to $18.0 \mathrm{~h}$ (median $9.0 \mathrm{~h}$ ). These durations of symptoms and delays to hospital arrival include nighttime sleep duration in three patients with symptom presentation on awakening.

The most common initial symptom or deficit was a sensory hemisyndrome in six patients. Mild hemiparesis was present in two patients and hand weakness in one. Cognitive function was impaired in the form of confusion in two patients and aphasia in three; sleepiness was also present in one of the latter (patient no. 1). Three patients (nos. 1, 2 and 7) had two TIA-like episodes, which were separated by 8 days, 8 days, and 5 h, respectively. There were no initial seizures, but patient no. 4 developed generalised myoclonia on day 2 and patient no. 6 a partial status epilepticus on day 4.

Meningeal signs were generally absent or minor. No patient had fever on arrival and five never developed fever. Patient no. 4 developed a fever of $38.0^{\circ} \mathrm{C}, 3 \mathrm{~h}$ after admission, attributed to and treated as urinary tract infection; LP was performed $72 \mathrm{~h}$ later when she developed 
status epilepticus. Elevated body temperature in patient no. 6 , at about $24 \mathrm{~h}$ after admission, was initially attributed to radiologically and microbiologically confirmed pneumonia (Streptococcus pneumoniae and Haemophilus influenzae in bronchoalveolar lavage specimen). LP was performed within $48 \mathrm{~h}$ because of worsening agitation and generalised myoclonias. There was mild to moderate headache in three patients, which started before the focal neurological symptoms in all cases. One patient complained of nausea and vomiting. Other meningeal symptoms and signs were absent (see Table 1).

Laboratory findings

The laboratory work-ups are described in Table 1 and were largely normal. CSF analysis was performed a median of $48 \mathrm{~h}$ after admission (range 6-96 h). CSF pleocytosis was mild to moderate (median $\mathrm{WBC} 105 / \mu \mathrm{L}$, range $10-190 /$

Table 1 Patient characteristics reported on first presentation in the emergency department, laboratory testing on admission, CSF findings on first testing and treatment

\begin{tabular}{|c|c|c|c|c|c|c|c|}
\hline Patient no. & 1 & 2 & 3 & 4 & 5 & 6 & 7 \\
\hline Age (years) & 45 & 22 & 58 & 75 & 41 & 36 & 64 \\
\hline Sex & $\mathrm{F}$ & $\mathrm{M}$ & $\mathrm{M}$ & $\mathrm{F}$ & M & M & $\mathrm{M}$ \\
\hline $\begin{array}{l}\text { Number of vascular risk } \\
\text { factors }{ }^{\mathrm{a}}\end{array}$ & 0 & 2 & 2 & 4 & 0 & 0 & 0 \\
\hline $\begin{array}{l}\text { Time from symptom } \\
\text { onset to first hospital } \\
\text { evaluation }(\mathrm{h})\end{array}$ & 17.0 & $9.0^{\mathrm{b}}$ & 1.6 & $18.0^{\mathrm{b}}$ & $10.0^{\mathrm{b}}$ & 2.5 & 3.5 \\
\hline $\begin{array}{l}\text { Duration of neurological } \\
\text { symptoms (min) }\end{array}$ & 1,020 & $510^{\mathrm{b}}$ & 45 & $1,050^{\mathrm{b}}$ & $510^{\mathrm{b}}$ & 210 & 195 \\
\hline \multicolumn{8}{|l|}{ Acute neurological deficit } \\
\hline $\begin{array}{l}\text { Speech and cranial } \\
\text { nerves }\end{array}$ & Aphasia & Normal & $\begin{array}{l}\text { Aphasia, } \\
\text { alexia, } \\
\text { agraphia }\end{array}$ & $\begin{array}{l}\text { Right central } \\
\text { facial } \\
\text { paralysis }\end{array}$ & $\begin{array}{l}\text { Mild right } \\
\text { central facial } \\
\text { paralysis }\end{array}$ & Normal & Aphasia \\
\hline Motor deficits & $\begin{array}{l}\text { Mild paresis of } \\
\text { left hand }\end{array}$ & No & No & $\begin{array}{l}\text { Right motor } \\
\text { hemisyndrome }\end{array}$ & $\begin{array}{l}\text { Right motor } \\
\text { hemisyndrome }\end{array}$ & No & No \\
\hline Sensory deficits & $\begin{array}{l}\text { Hypoaesthesia } \\
\text { of left hand }\end{array}$ & $\begin{array}{l}\text { Left perioral } \\
\text { and hand } \\
\text { paresthesias }\end{array}$ & No & $\begin{array}{l}\text { Right sensory } \\
\text { hemisyndrome }\end{array}$ & $\begin{array}{l}\text { Right sensory } \\
\text { hemisyndrome }\end{array}$ & $\begin{array}{l}\text { Right sensory } \\
\text { hemisyndrome }\end{array}$ & $\begin{array}{l}\text { Left sensory } \\
\text { hemisyndrome }\end{array}$ \\
\hline \multicolumn{8}{|c|}{ Meningeal symptoms and signs at presentation } \\
\hline Temperature $\left({ }^{\circ} \mathrm{C}\right)$ & $\begin{array}{l}35.6 \text { (on } \\
\text { analgesics) }\end{array}$ & 36.0 & 36.0 & 36.0 & 36.6 & 35.7 & 35.8 \\
\hline Headache & Yes & Yes & No & No & Yes & No & No \\
\hline Vomiting/nausea & Yes & No & No & No & No & No & No \\
\hline $\begin{array}{l}\text { Rash, photophobia, } \\
\text { neck stiffness, } \\
\text { Kernig's and } \\
\text { Brudzinski's signs }\end{array}$ & No & No & No & No & No & No & No \\
\hline \multicolumn{8}{|l|}{ Blood tests } \\
\hline WBCs $\left(\times 10^{9} / \mathrm{L}\right)$ & 10.4 & 6.4 & 7.5 & 6.6 & 6.7 & 5.8 & 10.7 \\
\hline CRP (mg/L) & 57 & $<2$ & $<2$ & 20 & $<2$ & $<2$ & $<2$ \\
\hline Glucose (mmol/L) & 5.1 & 5.9 & 5.2 & 9.1 & 7.5 & 6.4 & 8.1 \\
\hline $\mathrm{Na}^{+}(\mathrm{mmol} / \mathrm{L})$ & 136 & 138 & 137 & 143 & 141 & 142 & 141 \\
\hline \multicolumn{8}{|l|}{ CSF examination } \\
\hline WBCs $(/ \mu \mathrm{L})$ & 75 & 152 & 126 & 97 & 105 & 10 & 190 \\
\hline $\begin{array}{l}\text { Polymorphonuclear } \\
(\%)\end{array}$ & 1.5 & 1.5 & 4 & 85 & 0.3 & 1.5 & 3.5 \\
\hline Lymphocytes (\%) & 90 & 94.5 & 92 & 15 & 94.5 & 90.5 & 95 \\
\hline $\mathrm{RBCs}(/ \mu \mathrm{L})$ & 0 & 2 & 20 & 4 & 28 & 387 & 1 \\
\hline Protein $(\mathrm{g} / \mathrm{L})$ & 0.500 & 0.821 & 0.570 & 0.924 & 1.373 & 1.157 & 1.355 \\
\hline Glucose (mmol/L) & 2.8 & 3.3 & 3.4 & 7.4 & 3.5 & 4.6 & 3.8 \\
\hline \multicolumn{8}{|l|}{ Treatment } \\
\hline $\begin{array}{l}\text { Initial cardiovascular } \\
\text { treatment }\end{array}$ & $\begin{array}{l}\text { Aspirin } \\
300 \mathrm{mg}\end{array}$ & None & $\begin{array}{l}\text { Aspirin } \\
300 \mathrm{mg}\end{array}$ & Aspirin $300 \mathrm{mg}$ & None & $\begin{array}{l}\text { Intravenous } \\
\text { thrombolysis }\end{array}$ & Aspirin $100 \mathrm{mg}$ \\
\hline $\begin{array}{l}\text { Antimicrobial/antiviral } \\
\text { treatment }\end{array}$ & Both & Antiviral & $\begin{array}{l}\text { Not } \\
\text { documented }\end{array}$ & Both & Antiviral & Both & Both \\
\hline
\end{tabular}

$W B C$ white blood cell, $C R P$ C-reactive protein, $C S F$ cerebrospinal fluid, $R B C$ red blood cell

${ }^{a}$ Major vascular risk factors considered (other than age and sex): previous stroke/TIA, family history of stroke, current smoking, alcohol consumption, atrial fibrillation, hypertension, hypercholesterolaemia and diabetes mellitus

b Including nighttime sleep in patients with neurological symptoms present on awakening 
$\mu \mathrm{L}$ ), but clearly higher than we usually observe in stroke patients [4]. Lymphocytic predominance $>90 \%$ was evident in six patients and polymorphonuclear $(85 \%)$ in one. CSF protein concentration was elevated in all patients (median value $0.924 \mathrm{~g} / \mathrm{L}$, range $0.500-1.373 \mathrm{~g} / \mathrm{L}$ ). Five out of six patients in whom it was documented had a normal $\mathrm{CSF} /$ serum glucose index and one had an absolute decrease of glucose CSF levels $(2.8 \mathrm{mmol} / \mathrm{L})$. Further work-up to identify a causative agent was negative in all patients in both serum and CSF.

In the TIA group patients that were investigated with an LP, the examination was performed a median of 4.2 days after admission (interquartile range 2.0-6.5 days). CSF WBC was normal (median WBC $1 / \mu \mathrm{L}$, interquartile range $0.5-1 / \mu \mathrm{L}$ ), except for one patient who had borderline CSF pleocytosis (WBC $6 / \mu \mathrm{L}$ ), which we attributed to an imaging-proven cerebellar stroke 10 days earlier. CSF protein concentration was within the normal range (median value $0.428 \mathrm{~g} / \mathrm{L}$, interquartile range $0.345-0.516 \mathrm{~g} / \mathrm{L}$ ) in most patients.

\section{Imaging findings}

Six patients were initially investigated with NCCT and CTA and five also had an acute CTP. In patient no. 6, the CTP had movement artifacts and showed a possible prolongation of the mean transit time in the left hemisphere. On CTA, MRA and Doppler, three patients showed some atherosclerosis, with patient no. 7 being the only one with a $>50 \%$ stenosis, located at the origin of the right vertebral artery and, therefore, not explaining his aphasia and left sensory hemisyndrome. One female patient had brain MRI as the initial imaging and the others during hospitalisation. All MRIs were normal, except in patient no. 4, where meningeal thickening compatible with acute meningitis was revealed; in particular, no parenchymal findings suggestive of encephalitis was found, which is the most frequent situation in viral meningoencephalitis other than herpes virus [15]. No signs of cortical vein thrombosis were detected on T1, T2 and fluid-attenuated inversion recovery (FLAIR) images. An EEG was performed in six patients, with abnormal findings (generalised triphasic nonperiodical elements) only recorded in patient no. 4 with status epilepticus.

\section{Treatment and clinical outcome}

Five patients initially received cardiovascular drugs, including patient no. 6 with acute-onset right sensory hemisyndrome and confusional state (considered as fluent aphasia), who was erroneously thrombolysed with intravenous rtPA at $210 \mathrm{~min}$. The patient's hemisyndrome cleared quickly, but the subject then developed agitation requiring sedation and intubation, and pneumonia the next day. Aetiological work-up for stroke and meningoencephalitis was negative in all seven patients.

Antivirals and/or antibiotics were initially given for the meningoencephalitis in all six patients, where documented. All patients were discharged home after a median of 11 days (range 5-29 days) with complete remission of symptoms and no recurrent cerebral symptoms over the ensuing 3 months.

\section{Discussion}

We described seven consecutive adults presenting to a single stroke unit over a 9.75-year period with an acute, transient focal neurological deficit which imitated TIA but were finally diagnosed as viral meningoencephalitides. These patients were younger, had few cerebrovascular risk factors, often pure sensory symptoms and longer than usual duration of TIA. Meningeal symptoms, if present, were either minor or appeared later in the course. Of note, none had fever or meningism on admission. Brain and arterial work-up for causes of stroke was negative.

There are only sporadic case reports of meningitis as stroke mimic mainly associated with the presence of interesting (mostly bacterial) isolates in the culture results [16-25]. Data from meta-analyses also identify a low incidence of meningitis among stroke mimics [1, 2, 26-31]. Compared to other mimics that may be easier to diagnose, such as seizures (witness history), hypoglycaemia (acute glycaemia measures), migraine with aura (history of progressive onset, focal headaches), peripheral vestibular dysfunction (positive head thrust or caloric middle ear testing) and systemic infection (fever, CRP, WBC), meningoencephalitis may be more difficult to suspect and exclude.

In our population, the arguments to search for an alternative diagnosis were several: first, the patients were rather young and had few stroke risk factors, apart from one elderly patient with diabetes and hypertension (patient no. 4). Secondly, transient pure or predominant hemisensory symptoms were frequent. Thirdly, the duration of symptoms was rather long, with a median of 510 min, whereas TIAs typically last $10-180 \mathrm{~min}$ [3]. Fourth, there were sometimes minor meningeal symptoms and signs which are rare in strokes and TIAs: (mild) headache, confusional state, nausea or vomiting; in some patients, such symptoms, including fever and epileptic seizures, appeared during hospitalisation. Fifth, all patients had negative brain imaging, and, lastly, work-up for stroke did not reveal significant embolic sources.

In one of our patients, an erroneous thrombolysis decision was made partially based on the over-interpretation of 
subtle focal abnormalities on a CTP with movement artefacts; this intervention remained without serious consequences [31, 32]. Intravenous thrombolysis may be given occasionally for stroke mimics [31,32]; this is not only due to atypical clinical presentations that may not be recognised, but also to the little time available for emergency room physicians and neurologists before taking treatment decisions $[33,34]$. Furthermore, the poor sensitivity of NCCT as compared to CTP and, in particular, DWI MRI [35] can partially explain why there is no golden standard for skipping the stroke-mimic trap.

Limitations of our study include the fact that we were unable to confirm the presence of a viral agent in any of our patients. This may be due to the sensitivity of CSF PCR, which varies with different viruses, and can be dramatically influenced by the timing of specimen collection in relation to the onset of illness [36]. Other possible explanations of negative CSF PCRs include unknown infectious agents, unusual infectious agents not covered in the tests employed or known agents missed because of false-negative PCRs [36]. Recent studies on patients with typical presentation of meningitis or encephalitis lead to 43 and $17 \%$ of a PCRproven diagnosis, respectively, questioning whether these relatively small identified proportions constitute the total number of infective causes [37].

The fact that the aetiologic agent was not identified in our patients raises the question as to whether any of them were misclassified as meningoencephalitides instead of TIAs. However, previous studies in stroke patients showed that 70-90 \% of ischaemic cerebrovascular events are accompanied by normal CSF WBCs [38]. Similarly, in another study including patients with ischaemic stroke and clear CSF, no value $>10 \mathrm{WBCs} / \mu \mathrm{L}$ was recorded [39]. In the latter study, CSF protein values were $<0.50 \mathrm{~g} / \mathrm{L}$ in $62 \%$ of measured cases and only slightly elevated $(0.5-1.0 \mathrm{~g} / \mathrm{L})$ in $38 \%$. Recent studies prove that the elevation of specific protein molecules in CSF tested, such as S100B, is correlated with stroke severity and infarct volume, challenging the attribution of elevated CSF protein to a probable TIA [4]. In TIA patients, milder CSF abnormalities should also be expected, taking into account the absence of permanent brain damage compared to strokes. The CSF results of our TIA patients that were investigated with an LP match the above-mentioned reports and support our hypotheses that the CSF abnormalities in our patients should, most probably, not be attributed to TIAs.

Of note, other causes of non-viral aseptic meningitis such as drugs (e.g. trimethoprim-sulphamethoxazole or non-steroidal anti-inflammatory drugs), leptomeningeal cancer, sarcoidosis or immune-mediated diseases (e.g. systemic lupus erythematosus or CNS vasculitis) may be rather safely excluded by patients' history, clinical examination, laboratory and imaging studies, and the benign course of the symptoms.
We cannot exclude that some of our patients with headache may had a syndrome of transient headache and neurological deficits with CSF lymphocytosis (HaNDL); however, the onset of focal symptoms was abrupt in our patients, headaches were absent or minor, and other episodes of headache and neurological deficits did not recur within the first 3 months [40]. Another possible diagnosis could be viral-meningitis-associated vasculopathy; however, this seems rather unlikely based on the clinical history (e.g. absence of previous trigeminal zoster and rash, as in cases of varicella zoster virus infection) and the negative radiological findings (CTA and MRI), despite the fact that small-artery abnormalities cannot always be safely excluded [41, 42]. Moreover, we may have missed a diagnosis of meningoencephalitis in some other patients presenting as TIA because we do not perform LP in all our patients with a TIA diagnosis.

Rapid and correct diagnosis of TIA and stroke is of paramount importance, since aggressive work-up and early prevention of recurrences [43], acute treatment of strokes [34] and admission to stroke units are highly effective interventions [44].

In conclusion, meningoencephalitis should be part of the differential diagnosis in patients with a suspected TIA. The decision to perform an LP should be made on an individual basis and consider the presence of mild meningeal symptoms, age and other risk factors for vascular disease, the results of brain imaging and the basic diagnostic work-up for a stroke source.

Acknowledgments The authors acknowledge their sincere gratitude to M. Schluep, MD who contributed significantly in the retrieval of the LP results for the 27 TIA patients.

Conflict of interest On behalf of all the authors, the corresponding author states that there is no conflict of interest.

\section{References}

1. Hand PJ, Kwan J, Lindley RI, Dennis MS, Wardlaw JM. Distinguishing between stroke and mimic at the bedside: the brain attack study. Stroke. 2006;37:769-75. doi:10.1161/01.STR.00002 04041.13466.4c.

2. Libman RB, Wirkowski E, Alvir J, Rao TH. Conditions that mimic stroke in the emergency department. Implications for acute stroke trials. Arch Neurol. 1995;52:1119-22.

3. Amort M, Fluri F, Schäfer J, Weisskopf F, Katan M, Burow A, Bucher HC, Bonati LH, Lyrer PA, Engelter ST. Transient ischemic attack versus transient ischemic attack mimics: frequency, clinical characteristics and outcome. Cerebrovasc Dis. 2011;32:57-64. doi:10.1159/000327034.

4. Petzold A, Michel P, Stock M, Schluep M. Glial and axonal body fluid biomarkers are related to infarct volume, severity, and outcome. J Stroke Cerebrovasc Dis. 2008;17:196-203. doi: 10.1016/j.jstrokecerebrovasdis.2008.02.002. 
5. Tena D, Solís S, Lainez S, Torralba M, Chacón P, Valdezate S, Sáez-Nieto JA, Bisquert J. Meningitis caused by Abiotrophia defectiva: case report and literature review. Infection. 2012. doi: 10.1007/s15010-012-0318-6.

6. Joob B, Wiwanitkit V. Concurrent dengue virus and Japanese encephalitis virus infection. Infection. 2012. doi:10.1007/s15010012-0311-0.

7. Benjamin LA, Kelly M, Cohen D, Neuhann F, Galbraith S, Mallewa M, Hopkins M, Hart IJ, Guiver M, Lalloo DG, Heyderman RS, Solomon T. Detection of herpes viruses in the cerebrospinal fluid of adults with suspected viral meningitis in Malawi. Infection. 2012. doi:10.1007/s15010-012-0292-z.

8. Bozzola E, Krzysztofiak A, Bozzola M, Calcaterra V, Quondamcarlo A, Lancella L, Villani A. HHV6 meningoencephalitis sequelae in previously healthy children. Infection. 2012;40:5636. doi:10.1007/s15010-012-0295-9.

9. Yasar KK, Pehlivanoglu F, Sengoz G, Ayrancioglu N. A case of tuberculous meningitis with multiple intracranial tuberculomas and miliary tuberculosis and choroid tubercles. Infection. 2011;39:395-6. doi:10.1007/s15010-011-0144-2.

10. Ben Shimol S, Einhorn M, Greenberg D. Listeria meningitis and ventriculitis in an immunocompetent child: case report and literature review. Infection. 2012;40:207-11. doi:10.1007/s15010011-0177-6.

11. Figueiredo CA, Oliveira MI, Afonso AM, Curti SP, Durigon EL. Rubella encephalitis in a young adult male: isolation and genotype analysis. Infection. 2011;39:73-5. doi:10.1007/s15010-0100068-2.

12. World Health Organization (WHO). Cerebrovascular disorders: a clinical and research classification. WHO offset publication no. 43. Geneva: WHO; 1978.

13. Michel P, Odier C, Rutgers M, Reichhart M, Maeder P, Meuli R, Wintermark M, Maghraoui A, Faouzi M, Croquelois A, Ntaios G. The Acute STroke Registry and Analysis of Lausanne (ASTRAL): design and baseline analysis of an ischemic stroke registry including acute multimodal imaging. Stroke. 2010;41:2491-8. doi:10.1161/STROKEAHA.110.596189.

14. Rey V, Du Pasquier R, Muehl A, Péter O, Michel P. Multiple ischemic strokes due to Borrelia garinii meningovasculitis. Rev Neurol (Paris). 2010;166:931-4.

15. Davis LE. Diagnosis and treatment of acute encephalitis. Neurologist. 2000;6:145-59.

16. Romi F, Kråkenes J, Aarli JA, Tysnes OB. Neuroborreliosis with vasculitis causing stroke-like manifestations. Eur Neurol. 2004;51:49-50. doi:10.1159/000075090.

17. Townend BS, Hanson JA, Sturm JW, Whyte S. Stroke or encephalitis? Emerg Med Australas. 2005;17:401-4. doi:10.1111/ j.1742-6723.2005.00765.x.

18. Kulstad EB, Wichter MD. West Nile encephalitis presenting as a stroke. Ann Emerg Med. 2003;41:283.

19. Ingolfsdottir HM, Cayé-Thomasen P. Stroke? Localized, otogenic meningitis! Scand J Infect Dis. 2011;43:392-4. doi:10.3109/0036 5548.2010.534502.

20. Chen HW, Ding LW, Lai CC, Tseng TK, Liu WL. Japanese viral encephalitis mimicking stroke with an initial manifestation of hemiplegia. J Microbiol Immunol Infect. 2012;45:465-7. doi: 10.1016/j.jmii.2011.09.009.

21. Wipfler P, Pilz G, Lesicky O, Golaszewski SM, Ladurner G, Kraus J. Klebsiella meningoencephalitis presenting like embolic ischemic stroke. J Neurol. 2008;255:1983-4. doi:10.1007/ s00415-009-0046-8.

22. McKellar MS, Mehta LR, Greenlee JE, Hale DC, Booton GC, Kelly DJ, Fuerst PA, Sriram R, Visvesvara GS. Fatal granulomatous Acanthamoeba encephalitis mimicking a stroke, diagnosed by correlation of results of sequential magnetic resonance imaging, biopsy, in vitro culture, immunofluorescence analysis, and molecular analysis. J Clin Microbiol. 2006;44:4265-9. doi: 10.1128/JCM.00649-06.

23. Hsu SS, Kim HS. Meningococcal meningitis presenting as stroke in an afebrile adult. Ann Emerg Med. 1998;32:620-3. doi: 10.1016/S0196-0644(98)70044-7.

24. AbdulJabbar M, Ghozi I, Haq A, Korner H. Sudden 'stroke-like' onset of hemiparesis due to herpetic encephalitis. Can J Neurol Sci. 1995;22:320-1.

25. Klassen H, Klassen MK, Huncharek M. Group B streptococcal meningitis presenting as stroke in a nondebilitated man. Yale $\mathrm{J}$ Biol Med. 1995;68:1-6.

26. $\mathrm{Ng} \mathrm{CL}$. Diagnostic challenge—is this really a stroke? Aust Fam Physician. 2006;35:805-8.

27. Hatzitolios A, Savopoulos C, Ntaios G, Papadidaskalou F, Dimitrakoudi E, Kosmidou M, Baltatzi M, Karamitsos D. Stroke and conditions that mimic it: a protocol secures a safe early recognition. Hippokratia. 2008;12:98-102.

28. Huff JS. Stroke mimics and chameleons. Emerg Med Clin North Am. 2002;20:583-95.

29. Hemmen TM, Meyer BC, McClean TL, Lyden PD. Identification of nonischemic stroke mimics among 411 code strokes at the University of California, San Diego, Stroke Center. J Stroke Cerebrovasc Dis. 2008;17:23-5. doi:10.1016/j.jstrokecerebro vasdis.2007.09.008.

30. Scott PA, Silbergleit R. Misdiagnosis of stroke in tissue plasminogen activator-treated patients: characteristics and outcomes. Ann Emerg Med. 2003;42:611-8. doi:10.1016/S019606440300 4438.

31. Chen Y, Bogosavljevic V, Leys D, Jovanovic D, Beslac-Bumbasirevic L, Lucas C. Intravenous thrombolytic therapy in patients with stroke mimics: baseline characteristics and safety profile. Eur J Neurol. 2011;18:1246-50. doi:10.1111/j.14681331.2011.03367.x.

32. Artto V, Putaala J, Strbian D, Meretoja A, Piironen K, Liebkind $\mathrm{R}$, Silvennoinen $\mathrm{H}$, Atula S, Häppölä O; Helsinki Stroke Thrombolysis Registry Group. Stroke mimics and intravenous thrombolysis. Ann Emerg Med. 2012;59:27-32. doi:10.1016/ j.annemergmed.2011.09.011.

33. [No authors listed]. Tissue plasminogen activator for acute ischemic stroke. The National Institute of Neurological Disorders and Stroke rt-PA Stroke Study Group. N Engl J Med. 1995;333:1581-7. doi:10.1056/NEJM199512143332401.

34. Lees KR, Bluhmki E, von Kummer R, Brott TG, Toni D, Grotta JC, Albers GW, Kaste M, Marler JR, Hamilton SA, Tilley BC, Davis SM, Donnan GA, Hacke W; ECASS, ATLANTIS, NINDS and EPITHET rt-PA Study Group, Allen K, Mau J, Meier D, del Zoppo G, De Silva DA, Butcher KS, Parsons MW, Barber PA, Levi C, Bladin C, Byrnes G. Time to treatment with intravenous alteplase and outcome in stroke: an updated pooled analysis of ECASS, ATLANTIS, NINDS, and EPITHET trials. Lancet. 2010;375:1695-703. doi:10.1016/S0140-6736(10)60491-6.

35. Olivot JM, Albers GW. Diffusion-perfusion MRI for triaging transient ischemic attack and acute cerebrovascular syndromes. Curr Opin Neurol. 2011;24:44-9. doi:10.1097/WCO.0b013e 328341f8a5.

36. Davis LE, Tyler KL. Molecular diagnosis of CNS viral infections. J Neurol Neurosurg Psychiatry. 2005;76:10. doi:10.1136/ jnnp.2004.051698.

37. Kupila L, Vuorinen T, Vainionpää R, Hukkanen V, Marttila RJ, Kotilainen P. Etiology of aseptic meningitis and encephalitis in an adult population. Neurology. 2006;66:75-80. doi:10.1212/01. wnl.0000191407.81333.00.

38. Sörnäs R, Ostlund H, Müller R. Cerebrospinal fluid cytology after stroke. Arch Neurol. 1972;26:489-501.

39. Lee MC, Heaney LM, Jacobson RL, Klassen AC. Cerebrospinal fluid in cerebral hemorrhage and infarction. Stroke. 1975;6:638-41. 
40. Headache Classification Subcommittee of the International Headache Society. The International Classification of Headache Disorders: 2nd edition. Cephalalgia. 2004;24:9-160.

41. Steiner I, Kennedy PG, Pachner AR. The neurotropic herpes viruses: herpes simplex and varicella-zoster. Lancet Neurol. 2007;6:1015-28. doi:10.1016/S1474-4422(07)70267-3.

42. Nagel MA, Mahalingam R, Cohrs RJ, Gilden D. Virus vasculopathy and stroke: an under-recognized cause and treatment target. Infect Disord Drug Targets. 2010;10:105-11.
43. Johnston SC, Rothwell PM, Nguyen-Huynh MN, Giles MF, Elkins JS, Bernstein AL, Sidney S. Validation and refinement of scores to predict very early stroke risk after transient ischaemic attack. Lancet. 2007;369:283-92. doi:10.1016/S0140-6736(07) 60150-0.

44. Organised inpatient (stroke unit) care for stroke. Stroke Unit Trialists' Collaboration. Cochrane Database Syst Rev. 2007;4: CD000197. 